\title{
CHANGES IN THE ORGANIC ACIDS CONTENT DURING THE PRODUCTION OF THE PETROVAC SAUSAGE
}

Bojana Milićević1* ${ }^{\star}$ Bojana Danilović ${ }^{1}$, Natalija Džinić ${ }^{2}$ Dragiša Savić1

1 University of Niš, Faculty of Technology, Leskovac, Serbia

2University of Novi Sad, Faculty of Technology, Serbia

The activity of lactic acid bacteria during the production of fermented sausages induces the accumulation of organic acids and affects the final product characteristics. The changes in the organic acids content during the production are mainly affected by the production parameters and the diversity of lactic acid bacteria microbiota. The aim of this work is monitoring of organic acids (lactic, acetic and citric acids) during the production of the Petrovac sausage produced under different conditions. The results indicated the presence of lactic, citric and acetic acid. During the ripening of sausages, lactic acid was detected in all the samples and in the highest concentrations (1.3-22.5 mg/g). The increase in the concentration of lactic acid was more significant compared to the increase of acetic and citric acid.
(ORIGINAL SCIENTIFIC PAPER) UDC 637.524:547.29:579.6

Keywords: fermented sausages, lactic acid, acetic acid, citric acid

\section{Introduction}

A wide variety of fermented sausages which are produced all over the world is influenced by geographic, ethnical and climate characteristics of local areas [1]. The Petrovac sausage (Petrovská klobása) is a traditional dry fermented sausage made in Bački Petrovac, in the province of Vojvodina [2]. It is a high-quality fermented product with the appropriate texture, spicy aroma, produced without additives or preservatives and protected by Serbian law as a designation of origin at the national level [3].

The quality of traditionally fermented sausages is affected by various factors such as a raw material selection, a microbial metabolic activity and physicochemical changes during the smoking, ripening and drying process. The microbiota of traditionally fermented sausages originates from the environment or raw materials used in the production [4]. Lactic acid bacteria ( $L A B)$ and coagulase-negative cocci $(\mathrm{CNC})$ are primarily responsible for the sausage fermentation, while moulds and yeasts contribute to the flavour and visual characteristics of the product [5].

The main activity of LAB microbiota is the acid production which induces the reduction of $\mathrm{pH}$ value. This contributes to the development of texture, flavour and colour, prevents the growth of pathogenic microbiota and improves the stability and safety of the product $[6,7]$. On the other hand, the formation of organic acids may have a negative effect on the sausage quality, since some of them can be associated with the undesirable rancidity taste [8].

The production of organic acids in fermented sausages has been reported in many papers. In most cases the lactic, acetic and citric acids were detected [9-15]. Their production depends on chemical, physical and microbiological reactions [16]. In some cases propanoic, 2- methylpropanoic, butanoic, 2- methylbutanoic, 3- methylbutanoic, pentanoic, hexanoic, heptanoic and octanoic acids were also present [12-15].

Lactic acid, as the main product of LAB metabolism, has been detected in the highest concentration in different fermented sausages. The increase of lactic acid concentration during the production process was observed in the Northern-European type of the fermented sausages [9], Croatian fermented sausage "Slavonski kulen" [11], fermented horse meat sausages [19], "Salchichón" sausages [10], Belgian type salami and Boulogne sausages [15]. On the other hand, the presence of yeast and mould microbiota, for example Penicillium aurantiogriseum, may cause the decrease of the lactic acid content [10, 20, 21].

The acetic acid was detected as a volatile compound in low-acid sausages [13], Belgian type salami and Boulogne sausages [15] and in sausage minces and fermented sausages produced with starter cultures Staphylococcus carnosus and Staphylococcus xylosus [17, 18]. The significant increase of the acetic acid concentration during the fermentation was observed in slow dry fermented sausages with the addition of nitrate and nitrite [12] and dry fermented "Salchichón" sausages [10]. Although yeasts (Debaryomyces spp.) and moulds (Penicillium spp.) contribute to the stabilization of desired sensory properties of fermented meat products [22], they can increase the acetic acid content [10, 23].

Conversely to the frequent detection of lactic and acetic acid, the citric acid was rarely present in fermented sausages [10]. Piruvic, succinic, formic, propionic and n-butyric acids were detected in fermented "Salchichón" sausages [10], while pentanoic, 2-methylpropanoic, butanoic and 3-methylbutanoic acids were detected in low-acid sausages [13].

\footnotetext{
*Author address: Bojana Milićević, Faculty of Technology, University of Niš,

Bulevar Oslobođenja 124, 16000 Leskovac, Serbia

E-mail: bojanamilicevic@rocketmail.com

The manuscript received: June, 25, 2018.

Paper accepted: August, 17, 2018
} 
Marco et al. (2006) reported the presence of pentanoic, propanoic, butanoic, heptanoic and octanoic acids as volatiles in fermented sausages. In fermented sausages made with Staphylococcus spp. starter culture 2-methylpropanoic acid was also detected [18]. Butanoic, 2- methylbutanoic and 3- methylbutanoic acids were detected in the meat batter as volatiles produced by St. carnosus [17, 24] and St. xylosus [17, 18]. The increase of acetic, propionic and $\mathrm{n}$ - butyric acids is mainly caused by mould microbiota [10]. This study was conducted in order to define the changes of the concentration of organic acids during the production of the Petrovac sausage prepared and fermented under different process conditions. The changes in the process conditions included the use of non-starter cultures for starting the fermentations which were further performed in traditional or strongly controlled conditions.

\section{Experimental}

\section{Sausage production}

Fermented sausages were prepared according to the traditional recipe in Bački Petrovac. Meat batter was prepared of fresh minced pork ( $85 \%$ ) and solid back fat tissue $(15 \%)$. In the total weight of minced muscle and fat tissue the following ingredients $(\% \mathrm{w} / \mathrm{w})$ were added: red hot pepper $(2.50 \%)$, salt $(1.80 \%)$, garlic $(0.20 \%)$, cumin $(0.20 \%)$ and sucrose $(0.15 \%)$. The production parameters applied and sampling time during ripening are presented in Table 1 . Sausages A were made of partly chilled meat (about $3 \mathrm{~h}$ post-mortem), while all other sausages were made of chilled meat (about $24 \mathrm{~h}$ post-mortem). Sausages A, B1, F1 and F2 were produced under traditional conditions (smoking for $10-15$ days (4-8 $\mathrm{h}$ a day); temperature $<11^{\circ} \mathrm{C}\left(8,3^{\circ} \mathrm{C}-10,7^{\circ} \mathrm{C}\right)$; relative air humidity $\sim 60 \%$; drying and ripening for 60 days at the temperature around $0{ }^{\circ} \mathrm{C}$ ).

However, sausages B2, G1 and G2 were produced under controlled conditions (smoking for up to 3 days; temperature $20{ }^{\circ} \mathrm{C}$; relative air humidity $75 \%$; drying and ripening for 45 or 60 days at the temperature $\sim 10{ }^{\circ} \mathrm{C}$ ). The process of smoking in controlled conditions was performed in the industrial chamber (Wemag Micromat, Deutschland) with the smoke generator (Wemag Raucher zenger H504, Deutschland) by a pyrolysis process of beech wood smoke at $20^{\circ} \mathrm{C}$. The duration of the smoking process was $3 \mathrm{~h}$ (sausages $\mathrm{G} 1$ and G2) and 6h (3 days for $2 \mathrm{~h}$ ) (B2). Sausages F2 and G2 were made with the addition of the starter culture $(90 \%$ Lb. sakei and $10 \%$ Staphylococcus $\mathrm{sp}$.) while other samples were made without it.

Table 1. The Petrovac sausage production parameters and sampling time

\begin{tabular}{|c|c|c|c|c|}
\hline $\begin{array}{c}\text { Sample } \\
\text { mark }\end{array}$ & Meat & Addition of starter cultures & $\begin{array}{l}\text { Ripening } \\
\text { conditions }\end{array}$ & Sampling time (days) \\
\hline $\mathrm{A}$ & $\begin{array}{l}\text { Partly } \\
\text { chilled }\end{array}$ & No starter & Traditional & $\begin{array}{c}0,2,6,9,12,15,30 \\
\text { and } 60\end{array}$ \\
\hline B1 & Chilled & No starter & Traditional & $\begin{array}{c}0,2,4,6,9,12,15,30 \\
\text { and } 60\end{array}$ \\
\hline B2 & Chilled & No starter & Controlled & $\begin{array}{c}0,2,4,6,9,12,15,30 \\
\text { and } 45\end{array}$ \\
\hline $\mathrm{F} 1$ & Chilled & No starter & Traditional & $\begin{array}{l}0,2,9,15 \\
\text { and } 60\end{array}$ \\
\hline $\mathrm{F} 2$ & Chilled & $\begin{array}{l}\text { Lactobacillus sakei and } \\
\text { Staphylococcus sp. }\end{array}$ & Traditional & $\begin{array}{l}0,2,9,15 \\
\text { and } 60\end{array}$ \\
\hline G1 & Chilled & No starter & Controlled & $\begin{array}{l}0,2,9,15 \\
\text { and } 60\end{array}$ \\
\hline $\mathrm{G} 2$ & Chilled & Lb. sakei and Staphylococcus sp. & Controlled & $\begin{array}{l}0,2,9,15 \\
\text { and } 60\end{array}$ \\
\hline
\end{tabular}

Traditional conditions $=$ smoking for $10-15$ days at temperature $<11^{\circ} \mathrm{C}$ at relative air humidity $\sim 60 \%$; drying and ripening for 60 days at the temperature around $0{ }^{\circ} \mathrm{C}$; Controlled conditions = smoking for up to 3 days at temperature $20{ }^{\circ} \mathrm{C}$ and relative air humidity $75 \%$; drying and ripening for 45 or 60 days at the temperature $\sim 10{ }^{\circ} \mathrm{C}$

\section{Determination of organic acid concentrations}

In order to determine organic acid concentrations in sausage samples, the extraction procedure was applied. The extraction of organic acids was carried out by mixing $4 \mathrm{~g}$ of the sausage sample and $10 \mathrm{~cm}^{3}$ of $5 \mathrm{mM} \mathrm{H}_{2} \mathrm{SO}_{4}$ on a magnetic stirrer for $1 \mathrm{~h}$. For the precipitation of the proteins, 0.1 $\mathrm{cm}^{3}$ of Carrez $1\left(150 \mathrm{~g} / \mathrm{dm}^{3} \mathrm{~K}_{4}\left[\mathrm{Fe}(\mathrm{CN})_{6}\right] \times 3 \mathrm{H}_{2} \mathrm{O}\right)$ and Carrez $2\left(300 \mathrm{~g} / \mathrm{dm}^{3} \mathrm{ZnSO}_{4} \times 7 \mathrm{H}_{2} \mathrm{O}\right)$ were added. The samples were centrifuged for $15 \mathrm{~min}$ at $5000 \mathrm{rpm}$ and the supernatant was filtered through a microfilter with a pore size of $0.45 \mu \mathrm{m}$.

The detection of organic acids was performed on Aminex HPX-87H column (7.8 x $300 \mathrm{~mm}$, Biorad Laboratories) on a chromatograph (Agilent 1100 Series) in isocratic conditions [25]. The sample volume of $20 \mu \mathrm{l}$ was injected into the column and eluted with $5 \mathrm{mM} \mathrm{H}_{2} \mathrm{SO}_{4}$ [25]. Operating con- ditions were the column temperature of $50{ }^{\circ} \mathrm{C}$ and a flow rate of $0.6 \mathrm{~cm}^{3} / \mathrm{min}$. The compounds (organic acids) were detected by UV detector at $214 \mathrm{~nm}$ wavelength, based on the comparison with standard retention times.

The quantitative determination of individual organic acids in the samples was calculated by using the calibration curves basis dependence of the surface below the peak from the concentrations of standard solutions of lactic, acetic and citric acids. All the experiments were performed in triplicate.

\section{Results and Discussion}

Changes in lactic acid content

The lactic acid content increased during the fermentation 
in all analyzed sausages (Table 2), while the initial and final content differ depending on the parameters of the production process. In sausages A, made from partly chilled meat, a significantly higher initial concentration of lactic acid was observed (11 mg/g). On the other hand, in sausages B1 and B2, the initial value of the lactic acid content was $1.3 \mathrm{mg} / \mathrm{g}$. In these sausages, the rapid increase in the lactic acid production was observed after 2 days of fermentation, as a result of the intensive growth of $L A B$ in the initial stage of the production [26]. The maximum value of the lactic acid content was achieved at the end of fermentation, 17.3, 22.5 and $15.1 \mathrm{mg} / \mathrm{g}$ for sausages A, B1 and B2, respectively (Table 2). Although the initial value of the lactic acid content in sausages $\mathrm{F} 1$ and $\mathrm{F} 2$ was almost identical, the concentration of lactic acid in the final product was significantly different (Table 2). The analysis of microbiota at the beginning of the fermentation in sausages F1 and F2 showed the greater presence of LAB population in sausages F2 compared to sausages $F 1$, which caused the increased content of the lactic acid in sausages F2 [27]. Analysing the lactic acid content in sausages F1, F2, G1, and G2, it was observed that a higher content of lactic acid was detected in sausages produced with the addition of a starter culture compared to the sausages produced without a starter culture (Table 2).

The increase of the lactic acid content in the sausages and a high content at the end of the fermentation process is in accordance with literature data obtained for "Salcichőn" in which the detected value at the beginning of fermentation was $6.7 \mathrm{mg} / \mathrm{g}$ while at the end of fermentation the lactic acid content was $18 \mathrm{mg} / \mathrm{g}$ [10]. The increased lactic acid content was also in accordance with the data reported for North-European and Mediterranean types of fermented sausages [28]. The values reported in this paper were lower compared to Belgian and Bologna sausages in which the lactic acid content was $47.3 \mathrm{mg} / \mathrm{g}$ and $45 \mathrm{mg} / \mathrm{g}$, respectively [15].

Table 2. Changes in the lactic acid content $(\mathrm{mg} / \mathrm{g})$ during ripening of the samples of Petrovac sausages

\begin{tabular}{ccccccccccc}
\hline \multirow{2}{*}{ Samples } & 0 & 2 & 4 & 6 & 9 & 12 & 15 & 30 & 45 & 60 \\
\hline A & 11.0 & 11.0 & ND & 11.9 & 12.4 & 12.8 & 13.8 & 15.0 & ND & 17.3 \\
B1 & 1.3 & 10.4 & 12.9 & 13.4 & 14.0 & 13.6 & 13.7 & 15.6 & ND & 22.5 \\
B2 & 1.3 & 12.1 & 12.6 & 13.3 & 13.4 & 13.6 & 13.9 & 14.8 & 15.1 & ND \\
F1 & 7.2 & 6.4 & ND & ND & 8.0 & ND & 9.5 & ND & ND & 12.0 \\
G1 & 7.2 & 6.9 & ND & ND & 7.4 & ND & 13.2 & ND & ND & 19.8 \\
F2 & 7.8 & 11.7 & ND & ND & 8.5 & ND & 10.4 & ND & ND & 19.1 \\
G2 & 7.8 & 6.0 & ND & ND & 6.1 & ND & 15.8 & ND & ND & 23.0 \\
\hline
\end{tabular}

$\mathrm{ND}=$ not determined

\section{Changes in acetic acid content}

Acetic acid was not detected at the beginning of the process in all samples of sausages (Table 3). The highest concentrations of acetic acid during ripening were detected in the sausages marked $A$, while for the first time the acetic acid was detected after 6 days of fermentation $(1.7 \mathrm{mg} / \mathrm{g})$, and only slightly increased until 30th day of the process reaching $2.2 \mathrm{mg} / \mathrm{g}$ at the end of the fermentation. In samples B1, B2 and F2, the acetic acid content slightly varied in the range $0.4-1.0 \mathrm{mg} / \mathrm{g}$ from $2 \mathrm{nd}$ day till the end of ripening. In sausages B1, the highest content was detected after 15 days of the production process $(0.8 \mathrm{mg} / \mathrm{g})$ while in sausages B2 the highest value was detected at the end of the process (1 mg/g) (Table 3). A higher amount of acetic acid at the end of fermentation was detected in sausages produced of partly chilled meat $(2.2 \mathrm{mg} / \mathrm{g})$, probably as the result of the significant presence of heterofermentative Leuconostoc mesenteroides [26] in these samples. It was not detected in sausages $\mathrm{F} 1$ and $\mathrm{G} 2$ during the whole period of ripening (Table 3), while in samples G1 and F2 it was detected at the end of the production and after 2 days of fermentation, respectively. The low acetic acid content in sausages $\mathrm{F}$ and $G$ was in accordance with the low presence of Leuconostoc spp. in the isolated LAB microbiota [27].

The acetic acid is mainly produced by LAB microbiota, fatty acid oxidation and catabolic processes with alanine [10]. It contributes to the flavour of dried sausages [10, 13,
$18,29,30]$. The low initial acetic acid content in the analysed sausages was in accordance with the results obtained for "Salcichőn"(0.2 mg/g) [10]. On the other hand, the acetic acid content was much lower than those reported for Belgian sausage $(1.5 \mathrm{mg} / \mathrm{g})$ and Bologna sausage $(7.3 \mathrm{mg} / \mathrm{g})$ [15]. In some studies, it was found that the smoking process and the addition of nitrate/nitrite have an impact on the acetic acid production [18].

\section{Changes in citric acid content}

In sausages $A$, the citric acid content slightly varied during the fermentation in the range $0.4-0.7 \mathrm{mg} / \mathrm{g}$ (Table 4). In sausages B1 and B2 citric acid was not detected at the beginning of the fermentation, while after 30 days of fermentation the maximal content in these sausages was $0.7 \mathrm{mg} / \mathrm{g}$ (Table 4). Citric acid was detected almost on the same level of $0.3-0.4 \mathrm{mg} / \mathrm{g}$ in the meat batter of sausages F1, F2, G1 and G2. In F1 and G1, the initial concentration of $0.3 \mathrm{mg} / \mathrm{g}$ was detected while in sausages F2 and G2 the detected content was $0.4 \mathrm{mg} / \mathrm{g}$. During the fermentation process this content slightly increased and reached a maximum value at the end of fermentation (0.6-1.2 mg/g) (Table 4). The citric acid content at the beginning of the fermentation was in accordance with the data obtained for "Salcichőn". It was found that the citric acid content was not detected at the beginning of the fermentation process, while at the end of the fermentation the content was $0.3 \mathrm{mg} / \mathrm{g}$ [10]. 
Table 3. Changes in the acetic acid content $(\mathrm{mg} / \mathrm{g})$ during ripening of the samples of Petrovac sausages

\begin{tabular}{ccccccccccc}
\hline Samples & 0 & 2 & 4 & 6 & 9 & 12 & 15 & 30 & 45 & 60 \\
\hline A & 0.0 & 0.0 & ND & 1.7 & 1.8 & 2.0 & 2.4 & 2.7 & ND & 2.2 \\
B1 & 0.0 & 0.4 & 0.6 & 0.6 & 0.7 & 0.7 & 0.8 & 0.8 & ND & 0.8 \\
B2 & 0.0 & 0.5 & 0.5 & 0.6 & 0.6 & 0.6 & 0.7 & 0.9 & 1.0 & ND \\
F1 & 0.0 & 0.0 & ND & ND & 0.0 & ND & 0.0 & ND & ND & 0.0 \\
G1 & 0.0 & 0.0 & ND & ND & 0.0 & ND & 0.0 & ND & ND & 0.5 \\
F2 & 0.0 & 0.4 & ND & ND & 0.5 & ND & 0.6 & ND & ND & 0.7 \\
G2 & 0.0 & 0.0 & ND & ND & 0.0 & ND & 0.0 & ND & ND & 0.0 \\
ND=not determined & & & & & & & & &
\end{tabular}

Table 4. Changes in the citric acid content $(\mathrm{mg} / \mathrm{g})$ during ripening of the samples of Petrovac sausages

\begin{tabular}{ccccccccccc}
\hline \multirow{2}{*}{ Samples } & 0 & 2 & 4 & 6 & 9 & 12 & 15 & 30 & 45 & 60 \\
\hline A & 0.4 & 0.4 & ND & 0.4 & 0.4 & 0.7 & 0.5 & 0.6 & ND & 0.6 \\
B1 & 0.0 & 0.2 & 0.2 & 0.3 & 0.4 & 0.5 & 0.6 & 0.7 & ND & 0.6 \\
B2 & 0.0 & 0.0 & 0.3 & 0.6 & 0.6 & 0.6 & 0.5 & 0.7 & 0.4 & ND \\
F1 & 0.3 & 0.4 & ND & ND & 0.4 & ND & 0.7 & ND & ND & 0.9 \\
G1 & 0.3 & 0.4 & ND & ND & 0.6 & ND & 0.9 & ND & ND & 1.2 \\
F2 & 0.4 & 0.5 & ND & ND & 0.5 & ND & 0.6 & ND & ND & 1.1 \\
G2 & 0.4 & 0.3 & ND & ND & 0.5 & ND & 0.5 & ND & ND & 0.9 \\
\hline
\end{tabular}

$\mathrm{ND}=$ not determined

\section{Conclusion}

Determination of the organic acid content during the production of fermented sausages may contribute to the understanding of the changes of sensory characteristics during the production. In this study, lactic, acetic and citric acid were detected. The lactic acid was present in the highest amount in all analysed samples and its concentration increased during the production process regardless the production parameters. Also, the samples of Petrovac sausages produced with the addition of starter cultures had a higher amount of lactic acid. Acetic acid was randomly present in the samples, but in much lower concentrations. It is usually detected in the samples at the end of fermentation. The concentration of citric acid slightly varied during the production process.

\section{Acknowledgements}

This work was supported by the Ministry of Education, Science and Technological Development of the Republic of Serbia, grant No: 31032.

\section{References}

[1] M. Rašeta, S. Vesković-Moračanin, B. Borović, D. Karan, D. Vranić, D. Trbović, S. Lilić, Mikroklimatski uslovi tokom zrenja kobasica proizvedenih na tradicionalni način, Tehnologija Mesa, 51(1) (2010) $45-51$.

[2] V. Janković, Lj. Petrović, B. Lakićević, V. Sverak-Matekalo, S. Lilić, R. Mitrović, Determination of typical house flora during production process of the Petrovac Sausage (Petrovská klobása), African Journal of Microbiology Research, 32(7) (2013) 4130 - 4137.

[3] B. Danilović, N. Joković, Lj. Petrović, K. Veljović, M. Tolinački, D. Savić, The characterisation of lactic acid bacteria during the fermentation of an artisan Serbian sausage (Petrovská klobása), Meat Science, 88(4) (2011) 668 - 674.
[4] B. Borović, S. Vesković, B. Velebit, T. Baltić, D. Spirić, Dominantna mikroflora izolovana iz tradicionalno fermentisane "sremske“ kobasice, Tehnologija Mesa, 50(3-4) (2009) $227-231$.

[5] R. Talon, S. Leroy- Setrin, S. Fadda, in Research Advances in the Quality of Meat and Meat Products, F. Toldra Ed., Research singpost, Trivandrum, India, 2002, $175-191$.

[6] M. G. Bonomo, A. Ricciardi, T. Zotta, E. Parente, G. Salzano, Molecular and technological characterization of lactic acid bacteria from tradiitional fermented sausages of Basilicata region (Southern Italy), Meat Science, 80(4) (2008) 1238 - 1248.

[7] S. Leroy, P. Giammarinaro, J. P. Chacornac, I. Lebert, R. Talon, Biodiversity of indigenous staphylococci of naturally fermented dry sausages and manufacturing environments of small scale processing units, Food Microbiology, 27(2) (2010) $294-301$.

[8] A. Martinović, S. Vesković-Moračanin, Primena starter kultura u industriji mesa, Tehnologija Mesa, 47(5-6) (2006) $216-230$.

[9] F. Ravyts, L. Steen, O. Goemare, H. Paelinck, L. De Vuyst, F. Leroy, The application of Staphylococci with flavour- generating potential is affected by acidification in fermented dry sausages, Food Microbiology, 27(7) (2010) $945-954$.

[10] J. M. Bruna, J. A. Ordőňez, M. Fernandez, B. Herranz, L. de la Hoz, Microbial and physico-chemical changes during the ripening of dry fermented sausages superficially inoculated with or having added an intracellular cell-free extract of Penicillium aurantiogriseum, Meat Science, 59(1) (2001) 87 - 96.

[11] I. Babić, K. Markov, D., Kovačević, A. Trontel, A. Slavica, J. Đugum, D. Čvek, I. K. Svetec, S.Posavec, J. Frece, Identification and characterization of potential autochtonous starter cultures from a Croation "brand" product "Slavonski kulen", Meat Science, 88(3) (2011) $517-524$

[12] A. Marco, J. L. Navarro, M. Flores, The influence of nitrite on microbial, chemical and sensory parameters of slow dry fermented sausages, Meat Science, 73(4) (2006) 660 - 673. 
[13] M. Spaziani, M. Del Torre, M. L. Stecchini, Changes of physicochemical, microbiological and textural properties during ripening of Italian low-acid sausages, Proteolysis, sensory and volatile profiles, Meat Science, 81(1) (2009) $77-85$.

[14] F. Coloretti, G. Tabanelli, C. Chiavari, R. Lanciotti, L. Grazia, F. Gardini, C. Mantanari, Effect of wine addition on microbiological characteristics, volatile molecule profiles and biogenic amine contents in fermented sausages, Meat Science, 96(3) (2013) 1395 - 1402.

[15] M. Janssens, N. Myter, L. De Vuyst, F. Leroy, Species diversity and metabolic impact of the microbiota are low in spontaneously acidified Belgian sausages with an added starter culture of Staphylococcus carnosus, Food Microbiology, 29(2) (2012) 167 - 177.

[16] M. S. Ammor, B. Mayo, Selection criteria for lactic acid bacteria to be used as functional starter cultures in dry sausage production: An update, Meat Science, 76(1) (2007) 138 - 146.

[17] L. H. Stahnke, Volatiles produced by Staphylococcus xylossus and Staphylococcus carnosus during growth in sausage minces. Part I Collection and Identification, LWTFood Science and Technology, 32(6) (1999) 357 - 364.

[18] P. T. Olesen, A. S. Meyer, L. H. Stahnke, Generation of flavour compounds in fermented sausages- the influence of curing ingredients, Staphylococcus starter culture and ripening time, Meat Science, 66(3) (2004) 675 - 687.

[19] K. Markov, J. Frece, D. Čvek, A. Trontel, A. Slavica, D. Kovačević, Dominantna mikroflora fermentiranih kobasica od konjskog mesa, Meso, 12(4) (2010) 217 - 221.

[20] M. A. Dura, M. Flores, F. Toldra, Effect of Debaryomyces spp.on the proteolysis of dry-fermented sausages, Meat Science, 68(2) (2004) 319 - 328.

[21] L. Grazia, P. Romano, A. Bagni, D. Roggiani, G. Guglielmi, The role of moulds in the ripening process of salami, Food Microbiology, 3(1) (1986) 19 - 25.

[22] F. Lucke, Utilization of microbes to process and preserve meat, Meat Science, 56(2) (2000) 105 - 115.

[23] K. H. Gehlen, C. Meisel, A. Fischer, W. P. Hammes, in Handbook of Fermented Meat and Poultry, F. Toldra, Ed., Blackwell publishing, London, 1991, $871-876$.

[24] C. Larrouture, V. Ardaillon, M. Pepin, M. C. Montel, Ability of meat starter cultures to catabolize leucine and evaluation of the degradation products by using an HPLC method, Food Microbiology, 17(5) (2010) 563 - 570.

[25] S. Wang, C.Q.Fan, P. Wang, Determination of ultra-trace organic acids in Masson pine (Pinus massoniana L.) by accelerated solvent extraction and liquid chromatographytandem mass spectrometry, Journal of Chromatography B, 1-8, (2015) 981-982.

[26] B. Danilović, Changes in the population of lactic acid bacteria during the production of Petrovac sausage (Petrovská klobása). Thesis, Faculty of Technology, University of Nis, 2012.

[27] B. Milićević, B. Danilović, D. Savić, Promena mikrobiote bakterija mlečne kiseline tokom proizvodnje Petrovačke kobasice $\mathrm{u}$ tradicionalnim uslovima, in $\mathrm{X}$ simpozijum Savremene tehnologije i privredni razvoj, Tehnološki fakultet, Leskovac, 2013, $65-66$.

[28] K. Tjener, L. H. Stahnke, in Handbook of Fermented Meat and Poultry, F. Toldra Ed., Blackwell publishing, London, UK, 2007, 227 - 239.

[29] M. Montel, F. Masson, R. Talon, Bacterial role in flavour development, Meat Science, 49(1) (1998) 111 - 124.

[30] D. Demeyer, M. Raemaekers, A. Rizzo, A. Holck, A. De Smedt, B. Brink, B. Hagen, C. Montel, E. Zanardi, E. Murbrekk, F. Lerroy, F. Vandendriessche, K. Lorentsen, K. Venema, L. Sunesen, L. Stahnke, L. De Vuyst, L. Talon, R. Chizzolini, S. Eerola, Control of bioflavour and safety in fermented sausages: First results of an European project Food Research International, 33(3-4) (2000) 171 - 180.

\section{Izvod \\ PROMENA SADRŽAJA ORGANSKIH KISELINA TOKOM PROIZVODNJE PETROVAČKE KOBASICE}

Bojana Milićević1, Bojana Danilović1, Natalija Džinić², Dragiša Savić1

1 Univerzitet u Nišu, Tehnološki fakultet, Leskovac, Srbija

2Univerzitet u Novom Sadu, Tehnološki fakultet, Novi Sad, Srbija

Aktivnost bakterija mlečne kiseline tokom proizvodnje fermentisanih kobasica dovodi do akumulacije organskih kiselina i utiče na karakteristike konačnog proizvoda. Promene u sadržaju organskih kiselina tokom proizvodnje zavise uglavnom od proizvodnih uslova i raznovrsnosti mikrobiote bakterija mlečne kiseline.Cilj ovog rada je praćenje sadržaja organskih kiselina (mlečne, sirćetne i limunske kiseline) tokom proizvodnje Petrovačke kobasice proizvedene pod različitim uslovima. Rezultati pokazuju prisustvo mlečne, limunske i sirćetne kiseline. Tokom zrenja kobasica, mlečna kiselina je detektovana u svim uzorcima u najvišim koncentracijama (1.3-22.5 mg/g). Povećanje koncentracije mlečne kiseline bilo je značajnije u poređenju sa povećanjem sadržaja sirćetne i limunske kiseline.
(ORIGINALNI NAUČNI RAD) UDK 637.524:547.29:579.6
Ključne reči: fermentisane kobasice, mlečna kiselina, sirćetna kiselina, limunska kiselina 